\title{
Effect of Work Ethics and The Work Environment on Performance of Employees of PT. Berlian Indah Abadi Nusantara Surabaya
}

\author{
Firmansyah Anggarda Dewantara, Elok Damayanti \\ Faculty of Economics, Narotama University Surabaya, Indonesia \\ firmansyahdewantara99@gmail.com, elok.damayanti@narotama.ac.id
}

\begin{abstract}
This study aims to see the work ethic and work environment variables on the performance of the employees of PT Berlian Indah Nusantara Abadi Surabaya, partially or simultaneously. The method used in this method is quantitative and the data obtained from the distribution of questionnaires given to 57 employees, consisting of men mean 30 people while 27 women. Then for the analysis technique using multiple linear regression analysis processed using the SPSS version 21.00 program. From the research results, work ethics have a positive and significant effect on employee performance. Meanwhile, the work environment has a negative and significant effect on the work environment.
\end{abstract}

\section{Keywords:}

Employee Performance, Work Environment, Work Ethics

\section{Introduction}

The role of human resources is very important in achieving company goals. According to Hasibuan (2002) Human resources (HR) is the science and art of managing the relationships and roles of the workforce to be effective and efficient in helping the realization of company, employee and community goals. Especially in a trading business where there are many competing companies who share the same goal of developing and advancing the company, as in PT. Berlian Indah Nusantara Abadi Surabaya without the interference of company employees would not be able to progress and develop as it is today.

It is possible for a company to progress and develop which is also supported by a work ethic because ethics is also able to lead to a reflection of good and correct behavior And the work environment can also affect According to George R. Terry (2006: 23) in Ngalimun (2019)work environment can be defined as the forces that affect, either directly or indirectly, the performance of the organization or company. performance is performance equal to job performance, whose final result is calculated by comparing the work results with predetermined benchmarksBased on the description of the phenomenon above, the researcher is interested in conducting research with the title "Effect Of Work Ethics and The Work Environment on Employee Performance Pt Berlian Indah Nusantara Abadi Surabaya ".

\subsection{Formulation of the problem}

1. Are work ethics and work environment partially significant effect on employee performance?

2. Do work ethics and work environments simultaneously have a significant effect on employee performance?

\subsection{Purpose}

1. To analyze the effect of work ethics on employee performance at PT. Berlian Indah Nusantara Abadi Surabaya

2. To analyze the influence of the work environment on employee performance at PT. Berlian Indah Nusantara Abadi Surabaya

3. To analyze the effect of work ethics and work environment simultaneously on the performance of employees at PT.Berlian Indah Nusantara Abadi Surabaya.

\subsection{Theory Base}

1. Work ethic

Work ethics is a system of values or norms that are used by all company employees, including their leaders in their daily work. Companies with good work ethics will have and practice the values, namely: 
honesty, openness, loyalty to the company, consistency in decisions, good cooperation, discipline, and responsibility. The definition of Work Ethics is also defined by several experts including:

Obey Muhammad Djakfar (2013: 95-96) in Oktari (2018) work ethics are attitudes and views towards work, work habits of a person, a group of people or a nation.

Aspects of Work Ethics in According to Sinamo (2002: 29) quoted by Syaiful Sagala (2013: 292) in Oktari (2018)explained that there are eight aspects of work ethic. These aspects are:
a. Work is a gift.
b. Work is a mandate.
c. Work is a vocation.
d. Work is actualization.
e. Work is worship.
f. Work is an art.
g. Work is honor.
h. Work is service.

Factors Affecting Work Ethics According to Novliadi (2009: 112) quoted by Sukhidin (2017: 50) in Oktari (2018) Work ethic is influenced by several factors, namely:
a. Religion
b. Community Culture
c. Social and Political
d. Education Work ethic
e. Economic Structure work ethic indicators, namely:
a. Be responsible
b. Positive Work A positive work environment
c. Work Discipline
d. Persevere Someone
e. Work ethic education

Work Ethics Indicators According to Asifudin quoted by Alwiyah (2007: 98) in Nur aini et al (2020)

\section{Work environment}

Definition of the work environmentis a component part that is very, very important for an employee in carrying out work activities. By paying attention to a good work environment or creating good working conditionsJable to motivate employees to work, then it canHhave an influence on employee morale. The definition of the work environment is everything that is around the workers that can affect themselves in carrying out assigned tasks.

The work environment is measured using indicators by the following ratio, namely:
a. Work facilities, facilities and equipment
b. Safety and cleanliness
c. Air exchange
d. Lighting
e. Interpersonal relationships

\section{Employee performance}

Employee performance is the work achieved by a person in carrying out work tasks in accordance with his / her authority and responsibility in an effort to achieve organizational goals with indicators of completing tasks properly, obeying work procedures and rules, having initiative in work, maintaining work quality, behave well and be responsive to increased work demands, achieve the goals set according to the work agenda.

Factors Affecting Employee Performance According to Mathis and Jackson (2006: 83) in Veronika

(2018) factors that affect employee performance include the following:

a. Capability.

b. Motivation, support received.

c. The existence of the work they do and the relationships they accept.

d. The existence of the work they do and their relationship with the organization. According to Gibson, James L., John M. Ivancevich (2003) inVeronika (2018) individual performance is basically influenced by:

1) Expectations regarding rewards

2) Encouragement

3) Capabilities, needs and characteristics

4) Perception of duties 
5) Internal and external rewards

6) Perceptions of reward levels and performance satisfaction

Employee Performance IndicatorsAccording to Robbins (2006: 260) in Asty \& Krismawati (2016) indicators that can be used to assess employee performance are:
a. Work quantity
b. Quality of employee work.
c. Timeliness
d. Work commitment
e. Independence

\subsection{Research Hypothesis}

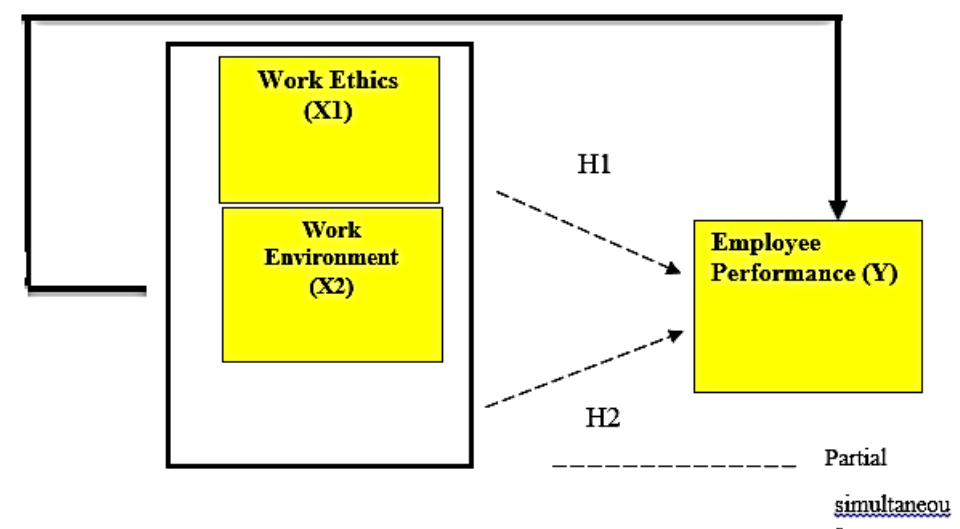

Figure 1. Research Hypothesis

H1 = Work ethic has a partially significant effect on employee performance

$\mathrm{H} 2=$ The work environment has a partial insignificant effect on employee performance

$\mathrm{H} 3$ = Work ethic and work environment have a significant effect simultaneously on employee performance.

\section{Research Methods}

This research is a field research with quantitative descriptive research. Quantitative descriptive research is research conducted by describing the independent variables and the dependent variables and proving the relationship of the independent variables into the dependent variable through hypothesis testing. The method used in this research is a quantitative method which emphasizes its analysis on numerical data (numbers) processed by statistical methods.

\subsection{Research Object}

The object of this research is carried out at PT.Berlian Indah Nusantara Abadi Surabaya which is located at Jl. Raya Nginden No.48 Surabaya. For the unit of analysis, namelyall employees at PT.Berlian Indah Nusantara Abadi.

\subsection{Population and Sample}

1. Population

According to Sugiyono (2016: 117) in Dewi et al. (2018) Population is the whole subject of research. "Population is a generalization area consisting of objects or subjects that have certain qualities and characteristics determined by the researcher to be studied and then draw conclusions".

\section{Sample}

According to Sugiyono (2010: 117) in Marantika (2017) The sample is part of the number and characteristics of the population. 


\section{JURNAL EKONOMI}

\subsection{Multiple Linear Regression Analysis}

The statistical test used is multiple linear regression analysis. Regression analysis is an approach used to define the mathematical relationship between the independent variables $(\mathrm{X})$ and the dependent variable (Y). The regression model is expressed in the equation.

\section{Research Results and Discussion}

Tabel 1. Research Results and Discussion

\begin{tabular}{cccc}
\hline $\begin{array}{c}\text { Item } \\
\text { Questions }\end{array}$ & rTable & rCalculate & Information \\
\hline X1.1 & 0.266 &, $475 * *$ & Valid \\
X1.2 & 0.266 &, $419 * *$ & Valid \\
X1.3. & 0.266 &, $499 * *$ & Vallid \\
X1.4 & 0.266 &, $773 * *$ & Valid \\
X1.5 & 0.266 &, $404 * *$ & Valid \\
X1.6 & 0.266 &, $465 * *$ & Valid \\
X1.7 & 0.266 &, $387 * *$ & Valid \\
X1.8 & 0.266 &, $478 * *$ & Valid \\
\hline Item & rTable & rCalculate & Information \\
Questions & & & Valid \\
X2.1 & 0.266 &, $696 * *$ & Valid \\
X2.2 & 0.266 &, $458 * *$ & Valid \\
X2.3 & 0.266 &, $862 * *$ & Valid \\
X2.4 & 0.266 &, $540 * *$ & Valid \\
X2.5 & 0.266 &, $789 * *$ & Valid \\
X2.6 & 0.266 &, $744 * *$ & Information \\
\hline Item & rTable & rCalculate & \\
Questions & & & Valid \\
Y.1 & 0.266 &, $607 * *$ & Valid \\
Y.2 & 0.266 &, $576 * *$ & Valid \\
Y.3 & 0.266 &, $583 * *$ & \\
Y.4 & 0.266 &, $789 * *$ &
\end{tabular}

From the table above we can conclude that all variables of Work Ethics (X1) Work Environment (X2) and Employee Performance (Y) are valid because they have a calculated $r$ value that exceeds the $r$ table, namely 0.266 .

\subsection{Reliability Test}

Table 2. Reliability Test

\begin{tabular}{cc}
\hline $\begin{array}{l}\text { Cronbach's } \\
\text { Alpha }\end{array}$ & N of Item \\
\hline, 698 & 18 \\
\hline
\end{tabular}

From the results of the calculation data of the reliability test above, the Cronbach's Alpha value is 698 out of 18 items in the questionnaire. This shows that the 18 items of the questionnaire statement have met the requirements for the reliability test, where if the Cronbach's Alpha reliability test results are $>0.6$ then it is declared reliable.

\subsection{Classical Assumption Result}

1. Normality test 


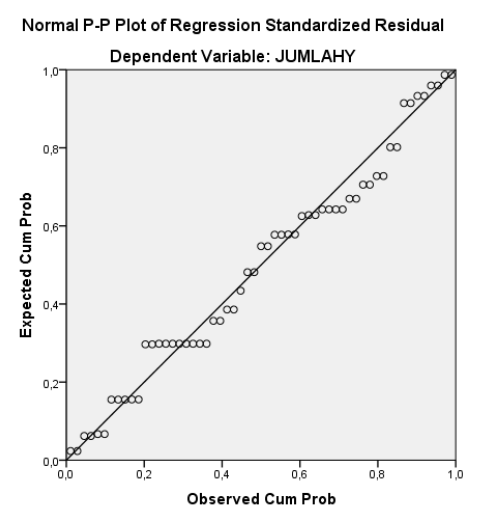

Figure 2. Normality test

The graphic above shows the distribution of the plots around and along the $45^{\circ}$ line, it can be concluded that the research variables are normally distributed.

2. Heteroscedasticity Test

Table 3. Heteroscedastity Test Table

\begin{tabular}{|c|c|c|}
\hline Variable & Sig & Conclusion \\
\hline Work Ethics & 0.77 & $\begin{array}{c}\text { Non- } \\
\text { heteroscedastity }\end{array}$ \\
\hline $\begin{array}{c}\text { Work } \\
\text { environment }\end{array}$ & 0.163 & $\begin{array}{l}\text { Non- } \\
\text { heteroscedastity }\end{array}$ \\
\hline
\end{tabular}

The table above shows that all variables have a value greater than 0.05 , it can be concluded that the entire table is non-heteroscedasticity.

\section{Multicollinearity Test}

Obtained the Tolerance value for Work Ethics Variable (X1) of .907 and for Work Environment Variable (X2) of, 907. Then obtained the VIF value for the Work Ethics variable (X1) of 1.217 and for the Work Environment Variable (X2) of 1.217. Based on the guidelines for the decision of Tolerance Value and VIF Value, it can be concluded that the two variables do not have multicollinearity symptoms because the two variable values meet the requirements.

\section{Hypothesis test}

Table 4. of Work Ethics and Work Environment Regression Analysis Test Results on Employee Performance of PT.Berlian Indah Nusantara Abadi Surabaya

\begin{tabular}{ccccc}
\hline Variable & \multicolumn{2}{c}{ t Count t Table Sig. } & \multicolumn{2}{c}{$\alpha$} \\
\hline Work Ethics & 6,958 & 2,00488 &, & 0.05 \\
Work & - & 2,00488 & 000 & \\
environment & 4,506 & & 000 & 0.05 \\
\hline
\end{tabular}

a. Hypothesis I Test

From the table above, the sig value is obtained. For the effect of $\mathrm{X} 1$ on $\mathrm{Y}$ of, 000 which means less than 0.05 and the value of $t$ count is 6.958> from the $t$ Table of 2.00488 so it can be concluded that H1, namely X1 or Work Ethics, has a positive and significant effect the Work Environment Then it can be concluded that the first hypothesis is accepted.

b. Hypothesis II Test 
From the table above, the sig value is obtained. For the effect of $\mathrm{X} 1$ on $\mathrm{Y}$ of, 000 which means less than 0.05 and the value of $\mathrm{t}$ count is $-4.506>$ from the $\mathrm{t}$ table of -2.00488 so it can be concluded that $\mathrm{H} 2$, namely X2 or the work environment, has a negative and significant effect on the work environment. Then it can be concluded that the second hypothesis is accepted.

\begin{tabular}{|c|c|c|c|c|c|c|}
\hline \multicolumn{7}{|c|}{$\begin{array}{c}\text { Tabel 5. F test } \\
\text { ANOVAa }\end{array}$} \\
\hline & Model & Sum of Squares & $\mathrm{df}$ & Mean Square & $\mathrm{F}$ & Sig. \\
\hline \multirow{3}{*}{1} & Regression & 62,927 & 2 & 31,464 & 27,349 & , $000 \mathrm{~b}$ \\
\hline & Residual & 62,125 & 54 & 1,150 & & \\
\hline & Total & 125,053 & 56 & & & \\
\hline
\end{tabular}

a. Dependent Variable: AMOUNT

b. Predictors: (Constant), QUANTITYX2, AMOUNTX1

c. Hypothesis Test III

Based on the results of the F test, a significant value is obtained for the effect of X1 and X2 simultaneously to $\mathrm{Y}$ is equal to $0.000<0.5$ and the value of $\mathrm{F}$ count is $27.349>\mathrm{F}$ table 3.16 so it can be concluded that $\mathrm{H} 3$ is accepted, which means that there is an influence of X1 (Work Ethics) and X2 (Work Environment) simultaneously on Y ( Employee performance).

\subsection{Determination correlation analysis ( $\mathrm{R} 2)$}

Tabel 6. Determination Correlation Analysis Model Summary b

\begin{tabular}{ccccc}
\hline Model & $\mathrm{R}$ & R Square & $\begin{array}{c}\text { Adjusted R } \\
\text { Square }\end{array}$ & $\begin{array}{c}\text { Std. Error of the } \\
\text { Estimate }\end{array}$ \\
\hline 1 &, $709 \mathrm{a}$ &, 503 &, 485 & 1,073 \\
\hline
\end{tabular}

a. Predictors: (Constant), QUANTITYX2, AMOUNTX1
b. Dependent Variable: AMOUNT

The coefficient of determination (R2) in essence measures how far the model's ability to explain variations in the dependent variable (Ghozali 2005). From the test results in this study, it was found that the R2 test value was 503 or $50.3 \%$, which means that the variables in this study only had an effect of $50.3 \%$ and the rest was influenced by other variables that were not examined in this study.

Table 7. Summary of Hypothesis Results of Multiple Linear Regression Test

\begin{tabular}{ccc}
\hline No & Hypothesis & Result \\
\hline 1. & Ewhen work affects performance & Proven \\
2. & Employees of PT. Berlian Indah Nusantara Abadi & Work Environment affects performance \\
& Employees of PT. Berlian Indah Nusantara Abadi & Proven \\
Work Ethics and Work Environment are influenti & Proven \\
& significant to the Employee Performance of PT. & \\
& Diamond & \\
& Indah Nusantara Abadi & \\
\hline
\end{tabular}

\section{Analysis and Discussion of Research Results}

\subsection{Effect of Work Ethics on Employee Performance}

The results showed that work ethics had a positive effect on employee performance at PT. Berlian Indah Nusantara Abadi Surabaya. This is evidenced by the results of the regression calculation which obtained a value of, 000 which means less than 0.05 and the $t$ value of $6.958>$ from the $t$ Table of 2.00488 so that it can be 
concluded that H1, namely X1 or Work Ethics, has a positive and significant effect on the Work Environment. With this, it can be concluded that the research can prove the first hypothesis.

\subsection{Effect of Work Environment on Employee Performance}

The results showed that the work environment had an effect negative on employee performance at PT. Berlian Indah Nusantara Abadi Surabaya. This is evidenced by the results of linear regression data processing who get the value sig. For the effect of $\mathrm{X} 2$ on $\mathrm{Y}$ of, 000 which means that is less than 0.05 and the value of $\mathrm{t}$ count is $-4.506>$ than $\mathrm{t}$ The table is -2.00488 so it can be concluded that $\mathrm{H} 2$ is $\mathrm{X}$ or the work environment has a negative and significant effect on Work environment. And with this it can be concluded that research can prove the second hypothesis.

\subsection{The Effect of Work Ethics and Work Environment on Employee performance}

The results of the study showed a significant value for the effect of X1 and X2 simultaneously on $\mathrm{Y}$ is equal to $0.000<0.5$ and the calculated $\mathrm{F}$ value of $27.349>\mathrm{F}$ table 3.16 so it can be concluded that $\mathrm{H} 3$ is accepted, which means there is an influence of X1 (Work Ethics) and X2 (Work Environment) simultaneously to Y (Employee Performance).

\section{Conclusions and Suggestions \\ 5.1. Conclusion}

Based on the results of research and discussion, several conclusions can be drawn. Work ethics have a positive effect on employee performance at PT. Berlian Indah Nusantara Abadi Surabaya.

1. The work environment has a negative effect on the performance of employees at PT. Berlian Indah Nusantara Abadi Surabaya.

2. Work Ethics have a simultaneous positive effect and the Work Environment has a simultaneous negative effect on Employee Performance at PT. Berlian Indah Nusantara Abadi Surabaya

\subsection{Suggestion}

Based on the research on the effect of work ethics and work environment, the work environment has a significant negative effect on employee performance with the results of linear regression data processing that get sig. For the effect of X2 on $\mathrm{Y}$ of, 000, which means less than 0.05 and the value of $\mathrm{t}$ count is $-4.506>$ from $\mathrm{t}$ Table of -2.00488. So it is suggested to the leadership of PT. Berlian Indah Nusantara Abadi Surabaya if the work environment decreases, it will affect employee performance, it is important for company leaders to create a healthy work environment in order to achieve maximum employee performance.

\section{References}

Asty, W., and K. Krismawati. 2016. “Analisis Loyalitas Terhadap Kinerja Karyawan Restoran Di Grand Rocky Hotel Bukittinggi.” Menara Ilmu 10 (60-65) 4(29).

Dewi, Sintya K., Sutopo, and Anggraeni Rahmasari. 2018. "Pengaruh Pelatihan Kerja , Disiplin Kerja , Dan Kompensasi Terhadap Kinerja Karyawan Pada PT . Campina Ice Cream Di Surabaya Rakhmat Yanuar Dwi Prasangka , Sutopo , Nurul Iman Prodi Manajemen Fakultas Ekonomi Dan Bisnis , Universitas Bhayangkara Surabaya." 4(3):415-23.

Ghozali, Imam. 2005. Aplikasi Analisis Multivariate Dengan SPSS. Semarang: Badan Penerbit UNDIP.

Gibson, James L., John M. Ivancevich, dan James H. Donnelly. 2003. Organizations Behaviour, Structure and Process. 8th Ed. Boston: Richard D. Irwin Inc.

Hasibuan, Malayu S. P. 2002. Manajemen Sumber Daya Manusia. Jakarta: PT Bumi perkasa.

Marantika, Dani. 2017. "Terhadap Prestasi Anak Menggunakan Metode Technology Acceptance Model." Konferensi Nasional Ilmu Sosial \& Teknologi (KNiST) 584-89.

Ngalimun. 2019. "Pengaruh Lingkungan Kerja Terhadap Kinerja Pegawai Pada Pt Perusahaan Gas Negara (Persero) Tbk Sbu Distribusi Wilayah I Jakarta.” Parameter 4(2). doi: 10.37751/parameter.v4i2.42.

Nur aini, Lilies, Fullchis Nurtjahjani, and Sanita Dhakirah. 2020. "Pengaruh Etika Kerja Dan Disiplin Kerja Terhadap Kinerja Karyawan Ony Comp Di Malang." Seminar Nasional Gabungan Bidang Sosial Polinema 2020.

Oktari, Rida. 2018. "Pengaruh Etika Kerja Dan Promosi Jabatan Terhadap Kinerja Karyawan Pada Pt.Tirta Sibayakindo Kabupaten Karo.” Journal of Materials Processing Technology 1(1):1-8.

Rahmawati, Nela Pima, Bambang Swasto, and Arik Prasetya. 2014. "Pengaruh Lingkungan Kerja Terhadap Kinerja Karyawan (Studi Pada Karyawan Kantor Pelayanan Pajak Pratama Malang Utara)." Jurnal Administrasi Bisnis (JAB) 8(2):1-9. doi: 10.37751/parameter.v4i2.41. 


\section{JURNAL EKONOMI}

Veronika, Nurmeini. 2018. "Pengaruh Disiplin Dan Pengawasan Kerja Terhadap Kinerja Karyawan Pada Pt. Tirta Sibayakindo Kabupaten Karo.” Journal of Materials Processing Technology 1(1):1-8.

\section{Biography}

Elok Damayanti is a senior lecturer at the Faculty of Economic and Business at Narotama University Surabaya. She received a Bachelor of Management degree from STIE Yapan Surabaya, and a Master of Management from Narotama University. Her research interests are in the field of Marketing and Human Resources Management. Firmansyah Anggarda Dewantara, student of Narotama University, Surabaya, Faculty of Economics and business, HR management study program. working as an employee of PT.Berlian Indah Nusantara Abadi. 